MANAGEMNET OF `KITIBHA KUSTHA- A SINGLE CASE STUDY

\title{
GAMIT $\mathbf{T}^{\mathbf{1}^{*}}$, MANU $\mathbf{R}^{2}$, AND CHAUHAN $\mathbf{D}^{3}$
}

1: Final year PG Scholar, Department of Kayachikitsa, Parul Institute of Ayurveda, Vadodara

2: Professor and H.O.D, Department of Kayachikitsa, Parul Institute of Ayurveda Vadodara

3: Final year PG Scholar, Department of Kayachikitsa, Parul Institute of Ayurveda, Vadodara

*Corresponding Author: Dr. Tarangna Gamit: E Mail: gamittarangna1677@gmail.com

Received 12 ${ }^{\text {th }}$ Dec. 2021; Revised $14^{\text {th }}$ Jan. 2022; Accepted $7^{\text {th }}$ Feb. 2022; Available online $5^{\text {th }}$ March 2022

\section{$\underline{\text { https://doi.org/10.31032/IJBPAS/2022/11.3.1093 }}$}

\begin{abstract}
Skin diseases are the most frequently occurring health problem which affects people of all ages. Usually $10-15 \%$ cases present before general practitioners are pertaining to skin diseases. In present era due to altered life style, less physical exercise, poor hygine, mental stress, eating habit, skin diseases are commonly observed. Psoriasis is one of the skin disorder which is more seen in present era due to stress and faulty lifestyle. Psoriasis has been mentioned our Ayurvedic classics as Kitibha kushta. The word Kushtha is a broad term used to describe almost all skin diseases in classical texts. Kitibha Kushtha is characterized by skin which is blackish brown in color, dry rough and hard to touch, black hard skin with severe itching. Due to similarity of symptoms it can be co-related with psoriasis. Psoriasis is chronic disorder which is commonly encountered in day to days clinical practice. Treatment of this disease is burning issue in todays era. This paper highlights a case study on kitibha kushta treated with Ayurvedic shaman aushadhis.
\end{abstract}

Keywords: Kitibha kushtha, Psoriasis, Shaman aushadhi, sthanika chikitsa INTRODUCTION

The word "psoriasis" has originated from the greek word 'Psora' which means itch. Psoriasis is a common chronic, immunemediated, inflammatory, proliferative, noncontagious disease of skin affecting people who are genetically predisposed, with environmental playing a critical role in the pathogenesis. The underlying pathology is a 10 fold increase in the rate of epidermal cell proliferation and exfoliation of 
nucleated cells before these form a horny layer. In psoriasis lesion consist of itchy, deep, pink to reddish, well demarcated, plaques with silvery-micaceous scaling present particularly over extensior surface. ${ }^{1}$ The prevalence of psoriasis in our society is increasing day by day. In india the prevalence of psoriasis varies from 0.44 to $2.8 \%$, it is twice more common in males compared to females, and most of the patients are in their third or fourth decade at the time of presentation. ${ }^{2}$ Because of recurrence and unsuccessful treatment, it is still challenge to the medical fraternity.

According to Ayurveda it can be correlated with Kitibha kushtha which comes under Eleven Kshudra Kushtas. according to Bruhatrayi. As per Ayurveda, all types of Kushtha are considered as Tridoshaja (Vata, pitta, kapha), they are caused by vitiation of all the three Doshas Seven Vyadhi ghatak are said to be responsible to manifestation of disease which are Tridosha. Twacha, Lasika, Rakta and Mamsa. ${ }^{3}$ According to Charaka, It is due to vitiation of Vata \& Kapha (Kitibham Prayo Vata Kaphadhikam). Due to vitiation of these two dosha the signs and symptoms of Kitibha are "Syavam Kina Kharasparsam Parusham Kitibhamam Smritam"-Kitibha is blackish brown in colour, rough in touch like a scar tissue, hard in touch. ${ }^{4}$ According to Susruta signs and symptoms of Kitibha are "Yat Sravi Vrittam Ghana Mugra Khandum Tat Snigdha Kushtam Kitibham Vadanti"- in Kitibha the eruptions exude a kind of secretion and which are circular, thick, excessively itching, glossy and black coloured.(5) According to Ashtanga hridaya the signs and symptoms of Kitibha are "Ruksham Kina Kharasparsam Kandumat Parushasitam". This reveals in Kitibha Kushta manifestation, the skin is blackish brown in colour, rough in touch like a scar tissue \& rigid in touch with itching. $^{6}$

\section{Case report}

A 42 years male patient visited in Parul Ayurveda hospital, department of Kayachikitsa OPD. (OPD NO.- 21016548) on $28 / 07 / 2021$.

\section{Pradhan vedana}

Blackish discolouration at back, both hands, legs and cervical region since 3 years

Itching since 3 years

Burning sensation feels since 3 years.

Scaling of skin after itching since 3 years

Dryness of skin.

\section{Vedanavruttanta}

Patient was apparently healthy before 3 year, after that developed blackish coloured skin lesion over upper and lower limb, back and cervical region associated with severe itching and scaling of skin. For these 
complains he consulted allopathy doctor

but couldn't get any relief from symptoms.

So he consulted to Parul Ayurveda hospital

for Ayurvedic treatment.

\section{Purva vedanavruttant}

No K/C/O- DM and HTN

\section{Kauthumbika vruttant}

All family members are said to be healthy

\section{Vyaktigata vruttant}

Ahara- Mixed (nonveg, once in a week)

Vihara:

- Addication- Alcohol, Tobacco

- Bowel habit- 2 times/day hard stool passed on pressure

- Sleep- Sound
- Urine- 4- 5 times/day, 1-2 times/night

\section{Occupational history}

Nature of work- standing working hours-

6 to 8 hours

\section{General examination}

Gait- Normal

Decubitus- Sitting

Faces- Normal

Pallor - Absent

Icterus- Absent

Cynosis- Absent

Oedema- Absent

Clubbing - Absent

Lymph nodes- Not palpable

Vital examination

\begin{tabular}{|c|c|}
\hline Pulse rate & $80 / \mathrm{min}$ \\
\hline Respiratory rate & $22 / \mathrm{min}$ \\
\hline Heart rate & $84 / \min$ \\
\hline Blood pressure & $140 / 80 \mathrm{mmhg}$ \\
\hline Temp. & $98.6^{0}$ \\
\hline
\end{tabular}

Ashtavidha pariksha

\begin{tabular}{|c|c|}
\hline Nadi & Vatapitta, 80/min \\
\hline Mala & 2 times/day \\
\hline Mutra & Sama \\
\hline Jihwa & Prakruta \\
\hline Shabda & Parush sparsha \\
\hline Sparsh & Prakrut \\
\hline Drika & Madhyam \\
\hline Aakriti &
\end{tabular}

Rogi pariksha

\begin{tabular}{|c|c|}
\hline Prakruti & Pittavata \\
\hline Vikruti & Madhyama \\
\hline Sara & Madhyama \\
\hline Samhanana & Madhyama \\
\hline Satwa & Madhyama \\
\hline Satmya & Madhyama \\
\hline Aaharshakti & Madhyama \\
\hline Vyayamshakti & Madhyama \\
\hline Pramana & Madhyama \\
\hline Vaya & Madhyama \\
\hline
\end{tabular}

Systemic examination

on upper and lower limb, no any

1. Locomotory system - on

Inspection, blackish discolouration other deformity

2. Respiratory system- B/L Lungs fields clear 
3. Cardiovascular system- $s_{1} s_{2}$ heard, no added sound

4. Central nervous system- consious and oriented about date, time and place

\section{Local examination}

Candle grease sign was positive.

Darshana- Dry cracked skin, small scaling spots

Sparsha- Thick and dry

Prashna- Itching and burning sensation

\section{Nidana}

Aahara- nonveg food and oily, spicy food

Manasika bhav-krodha and stress due to family problem.
Provisional diagnosis- Kitibha kushtha

\section{Differential diagnosis-}

Eka kushtha- There will be a mahavastu (Large lesion)

Sidhma kushtha - There will be shweta(Whitish), Tamra(Coppery) lesion. $\operatorname{Tanu}$ (Thin)

Kitibha kushtha - There will be shyavata(Blackish brown in colour) kina, khara sparsha(Rough in touch like scar tissue), Parushata(Hard in touch)

Diagnosis- Kitibha kushtha

Prognosis- Kruchchsadhya

Samprapti ghataka

\begin{tabular}{|c|c|}
\hline Dosha & Tridosha \\
\hline Dushya & Twka, Rakta, Mansa, Lasika \\
\hline Srotas & Rasavaha, Raktavaha \\
\hline Srotodushti prakara & Sanga \\
\hline Rogamarga & Bahya \\
\hline Udbhava sthana & Amashaya \\
\hline Vyakta sthan & Twacha \\
\hline Aama & Sama \\
\hline Agni & Jatharagnijanya \\
\hline Roga swabhava & Chirkari \\
\hline
\end{tabular}

\section{Samprapti}

Nidana sevana like aaharaja/viharaja/manasika

(Oily spicy food, consumption of alchohol, tobacco, non veg diet)

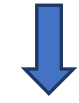

Tridosha+ Twaka, rakta, lasika, mansa

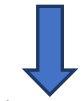

Sthansanshraya in Twacha

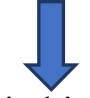

Discolouration with itching and scaling of skin

Kitibha kushtha 


\section{Treatment}

\begin{tabular}{|c|c|c|}
\hline $28 / 07 / 2021$ to $3 / 08 / 2021$ & $\begin{array}{l}\text { 1) } \\
\text { 2) } \\
\text { 3) } \\
\text { 4) }\end{array}$ & $\begin{array}{l}\text { Agnitundi vati } 1 \text { tabelt TID } \\
\text { Avipattikara churna } 1 \text { tsp at night with warm water } \\
\text { Chandraprabha vati } 1 \text { tabelt TID } \\
\text { Krimikuthara rasa } 1 \text { tabelt TID }\end{array}$ \\
\hline $3 / 08 / 2021$ to $11 / 8 / 2021$ & $\begin{array}{l}\text { 1) } \\
\text { 2) } \\
\text { 3) } \\
\text { 4) } \\
\text { 5) }\end{array}$ & $\begin{array}{l}\text { Avipattikara churna } 1 \text { tsp at night with warm water } \\
\text { Chandraprabha vati } 1 \text { tabelt TID } \\
\text { Krimikuthara rasa } 1 \text { tabelt TID } \\
\text { Mahamanjishthadi kwatha 30ml TID } \\
\text { Gandhaka rasavana } 1 \text { tablet TID }\end{array}$ \\
\hline $11 / 08 / 2021$ to $1 / 09 / 2021$ & $\begin{array}{l}\text { 1) } \\
\text { 3) } \\
\text { 4) } \\
\text { 5) } \\
\text { 6) }\end{array}$ & $\begin{array}{l}\text { Avipattikara churna } 1 \text { tsp at night with warm water } \\
\text { Chandraprabha vati } 1 \text { tabelt TID } \\
\text { Krimikuthara rasa } 1 \text { tabelt TID } \\
\text { Mahamanjishthadi } k \text { watha } 30 \mathrm{ml} \text { TID } \\
\text { Gandhaka rasayana } 1 \text { tablet TID } \\
\text { Karanja taila for L/A }\end{array}$ \\
\hline $1 / 09 / 2021$ to $15 / 09 / 2021$ & $\begin{array}{l}\text { 1) } \\
\text { 2) } \\
\text { 3) } \\
\text { 5) } \\
\text { 6) } \\
\text { 7) }\end{array}$ & $\begin{array}{l}\text { Avipattikara churna } 1 \text { tsp at night with warm water } \\
\text { Chandraprabha vati } 1 \text { tabelt TID } \\
\text { Krimikuthara rasa } 1 \text { tabelt TID } \\
\text { Mahamanjishthadi kwatha 30mI TID } \\
\text { Gandhaka rasayana } 1 \text { tablet TID } \\
\text { Karanja taila for L/A } \\
\text { Aarogyavardhini vati } 1 \text { tablet TID }\end{array}$ \\
\hline $15 / 92021$ to $22 / 09 / 2021$ & & Repeat same treatment \\
\hline $22 / 09 / 2021$ to $6 / 10 / 2021$ & $\begin{array}{l}\text { 1) } \\
\text { 2) } \\
\text { 4) } \\
\text { 5) } \\
\text { 6) } \\
\text { 7) } \\
\text { 8) } \\
\text { 9) }\end{array}$ & $\begin{array}{l}\text { Avipattikara churna } 1 \text { tsp at night with warm water } \\
\text { Chandraprabha vati } 1 \text { tabelt TID } \\
\text { Krimikuthara rasa } 1 \text { tabelt TID } \\
\text { Mahamanjishthadi kwatha 30mI TID } \\
\text { Gandhaka rasayana } 1 \text { tablet TID } \\
\text { Karanja taila for L/A } \\
\text { Aarogyavardhini vati } 1 \text { tablet TID } \\
\text { Vidangarishta \& khadirarishta } 2 \text { tsp each with half glass plaim water } 3 \\
\text { times a day } \\
\text { Tab.patoladi kasaya } 1 \text { tablet TID }\end{array}$ \\
\hline $6 / 10 / 2021$ to $13 / 10 / 2021$ & & Repeat same treatment \\
\hline $13 / 10 / 2021$ to $20 / 10 / 2021$ & & Repeat same treatment \\
\hline $20 / 10 / 2021$ to $15 / 11 / 2021$ & & Repeat same treatment \\
\hline $15 / 11 / 2021$ to $1 / 12 / 2021$ & & Repeat same treatment \\
\hline $1 / 12 / 2021$ to $8 / 12 / 2021$ & & Repeat same treatment \\
\hline
\end{tabular}

\section{OBSERVATION AND RESULTS:}

The improvement of the patient was assessed on the basis of PASI score. ${ }^{7}$

BEFORE TREATMENT

\begin{tabular}{|c|c|c|c|c|c|}
\hline Plaque Characteristic & Lesion Score & Head & Upper limb & Trunk & Lower limb \\
\hline Induration & \multirow{2}{*}{$\begin{array}{c}0=\text { None } \\
\text { 1=Slight } \\
2=\text { Moderate } \\
3=\text { Severe } \\
4=\text { very severe }\end{array}$} & 1 & 1 & 2 & 2 \\
\hline & & & & & \\
\hline Lesion score sum(A) & & 5 & 6 & 7 & 8 \\
\hline $\begin{array}{c}\text { Limbs } \\
\text { Area score (B) } \\
\text { (Degree of involvement } \\
\text { as a percentage for } \\
\text { each body region } \\
\text { affected) }\end{array}$ & $\begin{array}{c}0=0 \% \\
1=1 \%-9 \% \\
2=10 \%-29 \% \\
3=30 \%-49 \% \\
4=50-69 \% \\
5=70-89 \% \\
6=90-100 \% \\
\end{array}$ & 2 & 4 & 1 & 5 \\
\hline \multicolumn{6}{|c|}{$\begin{array}{l}\text { Multiplying each of subtotals I by amount of body surface area represented by that region, i.e x0.1 for head, x0.2 for upper } \\
\text { body, } \mathbf{x} 0.3 \text { for trunk and } 0.4 \text { for lower limbs }\end{array}$} \\
\hline Body surface area & & X 0.1 & X 0.2 & X 0.3 & X0.4 \\
\hline Totals (D) & & 1 & 4.8 & 2.1 & 16 \\
\hline \multicolumn{6}{|c|}{ Adding together each of the score for each body region to give the final PASI score } \\
\hline PASI SCORE & & & 23.9 & & \\
\hline
\end{tabular}




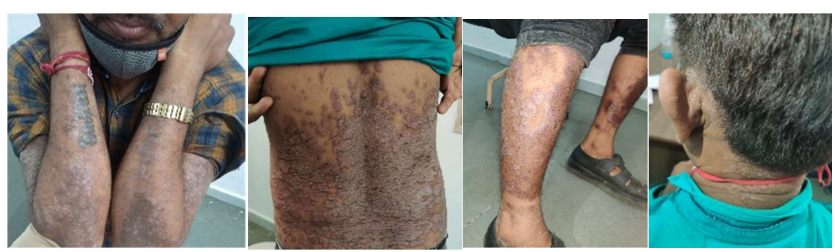

\begin{tabular}{|c|c|c|c|c|c|}
\hline \multicolumn{6}{|c|}{ AFTER TREATMENT } \\
\hline Plaque Characteristic & Lesion Score & Head & Upper limb & Trunk & Lower limb \\
\hline Erythema & \multirow{4}{*}{$\begin{array}{c}\text { 0=None } \\
\text { 1=Slight } \\
\text { 2=Moderate } \\
\text { 3=Severe } \\
\text { 4=very severe }\end{array}$} & 1 & 1 & 1 & 1 \\
\hline Induration & & 1 & 1 & $\mathbf{0}$ & 1 \\
\hline Scaling & & $\mathbf{0}$ & $\mathbf{0}$ & $\mathbf{0}$ & $\mathbf{0}$ \\
\hline & & & & & \\
\hline Lesion score sum(A) & & 2 & 2 & 1 & 2 \\
\hline Percentage area affected & Area score & Head & Upper limb & Trunk & Lower limb \\
\hline $\begin{array}{c}\text { Limbs } \\
\text { Area score (B) } \\
\text { (Degree of involvement } \\
\text { as a percentage for each } \\
\text { body region affected) }\end{array}$ & $\begin{array}{c}0=0 \% \\
1=1 \%-9 \% \\
2=10 \%-29 \% \\
3=30 \%-49 \% \\
4=50-69 \% \\
5=70-89 \% \\
6=90-100 \%\end{array}$ & 2 & 4 & $\mathbf{0}$ & 5 \\
\hline \multicolumn{6}{|c|}{ Multiplication of lesion score sum (A) by area score (B) for each body region to give 4 individual subtotals (C) } \\
\hline Subtotal I & & 4 & 8 & $\mathbf{0}$ & 10 \\
\hline \multicolumn{6}{|c|}{$\begin{array}{l}\text { Multiplying each of subtotals I by amount of body surface area represented by that region, i.e x0.1 for head, } \mathrm{x} 0.2 \\
\text { for upper body, } \mathbf{x 0 . 3} \text { for trunk and } 0.4 \text { for lower limbs }\end{array}$} \\
\hline Body surface area & & X0.1 & X0.2 & X0.3 & X0.4 \\
\hline Totals (D) & & 0.4 & 1.6 & $\mathbf{0}$ & 4 \\
\hline \multicolumn{6}{|c|}{ Adding together each of the score for each body region to give the final PASI score } \\
\hline PASI SCORE & & & 6 & & \\
\hline
\end{tabular}

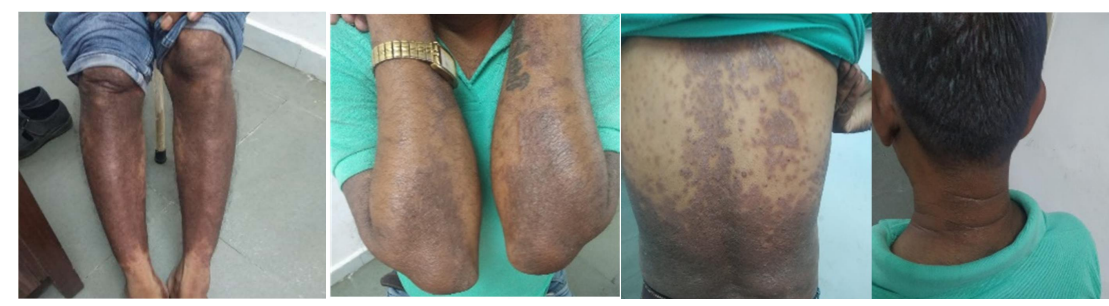

\begin{tabular}{|c|c|c|}
\hline Features & BT & AT \\
\hline Colour & Blackish & Reduced \\
\hline Itching & Severe & Absent \\
\hline Lesion size & Big and harder & Decreased \\
\hline Lesion number & More & 6 \\
\hline PASI score & $\mathbf{2 3 . 9}$ & Normal \\
\hline Depression & Present & Absent \\
\hline Scaling & Present &
\end{tabular}

\section{Pathya-Apathya}

Pathya- Aahara- Laghu aahara, Tikta rasayukta aahara, Purana dhanya, Mudga, Patol, Yava, Shashtik shali, Godhuma
Pathya- vihara- Snana, Shubhvastra dharana, Taila abhyanga, Yoga, Dhyana Apathya Aahara- Tila taila, Dhadhi, Madhya sevana, Mansa, Matsya sevana 
Apathya Aahara- Vegavidharana, Adhika vyayama

\section{Discusion}

\section{Agni deepan chikitsa :}

For Agni deepana we selected Agnitundi vati. As the name suggests Agni means Digestive fire, hence the one which improves Digestive fire. It contents Shudhdha parad (Purified Mercury), Shudhdha gandhaka (Purified sulphur), Ajamoda (Trachyspermum roxburghinum), Haritaki (Terminalia chebula), Bhibhitaki (Terminalia bellirica), Amalaki (Emblica officinalis), Sarjikshara, Yavakshara, Chitraka (Plumbago zeylanics), Saindhava lavana, Sauvarchala lavana, Samrudra lavana, Jiraka (Cuminum cyminum), Vidanga (Emblica ribes), Vishamushti (Purified strychnos nuxvomica) and Jambira swarasa (Lemon juice) for trituration. $^{8}$

Agnitundi vati is useful in kapha and Vatapradhan diseases. Agnitundi vati is an excellent drug of choice in Agnimandya and diseases caused by Mandagni. It contains drugs like Vatsanabha and Vishamushti having Vyavayi and Vikashi guna and Kajjali being Yogvahi and Sarvarogahara it enhances the potency of drug and give immediate effect. Kshara promotes Dipana and Pachana and do Ksharana of Kapha and corrects the formation of Pitta. Jirak, Ajmoda, Vidanga,
Chitrak etc helps to reduces the Guruta, Mrutsnatva of Kapha. Jambir nimbu, which are excellent appetizer by its Tikshna guna, Amla rasa and Amla vipaka, helps to Pitta utpadana and enhances Dipana and Pachana. $^{9}$

\section{For Nitya virechana}

Virechana pacify the morbid Pitta and help to carry out its function normally, hence helping the skin lesions to heal ${ }^{10}$ __Nitya Virechana removes the toxic materials from the body and provides purification of the body at two level: (1) gross level, where various organs and systems of the body are thoroughly cleansed, cardiovascular level and gastrointestinal tract, and (2) cellular level, where the purification and cleansing of the body is produced at cell membrane and molecules. Gut absorption improves considerably and metabolism is also corrected. $^{11}$

Avipattikara churna ${ }^{12}$ given as Nitya virecana.

Avipattikar churna, a polyherbal Ayurvedic formulation which is popular for the treatment of peptic ulcer, is composed of fourteen different ingredients, which include: Shunthi (Zingiber officinale), Maricha (Piper nigrum), Pippali (Piper longum), Haritaki (Terminalia chebula), Vibhitaka (Terminalia bellerica), Aamalaki (Emblica officinalis), Musta (Cyperus rotundus), Vida Lavana(salt), 
Vidanga (Embelia ribes), Ela (Amomum subulatum), Patra (Cinnamomum tamala), Lavanga (Syzgium aromaticum), Trivrit (Operculina terpethum) and Sharkara (Sugar candy) ${ }^{12}$

Avipattikar Churna has Mrudu Virechaka (mild laxative), Deepan, and Pachan properties. It causes removal of aggravated Doshas, corrects Agnimandya, and thereby removes Strotorodha. ${ }^{13}$

Krimikuthara rasa- It contents Karpura (Cinnamomum camphora), Indrayava (Holarrrhena antidysentrica), Ajamoda (Trachyspermum roxburghinum), Trayamana (Gentiana kurroo), Vidanga (Embelia ribes), Shudhdha Hingul (Purified cinnabar), Shudhdha Vatsnabha (Purified aconitum ferox), Nagakesara (Mesua ferrea), Palasha (Butea monosperma), Vijaya (Bhanga- Cannabis sativa, quantity sufficient for grinding for one day), Brahmi (Bacopa monnieri- Juice quantity sufficient for grinding).This drugs are having Ushna and Teekshna guna which is helpful in alleviating vitiated Vata and Kapha doshas ${ }^{14}$.Krimikuthara rasa have deworming action so it is helpful detoxifying the body. It promotes the biological membrane against oxidative stress. Inhibits the growth of bacteria. Clears the airways and stimulate the cell mediated immune mechanism. ${ }^{15}$

Vidangarishta- It contents Vidanga (Embelia ribes), Granthika- Pippali moola
(Piper longum), Kutaja (Hollarrhena antidysentrica), Patha (Cyclea peltata), Elavaluka (Prunus cerasus), Dhatri (Emblica officinalis), Dhataki (Woodfordia fruticose), Twaka (Cinnamomum tamala), Ela (Eletttaria cardamomum), Priyangu (Callicarpa macrophylla), Kanchnara (Bauhinia variegata), Lodhra (Symplocus racemosa), Shunthi(Ginger officinale), Marich (Piper nigrum), Pippali (Piper longum). These are Vata kaphahara and Kruminashaka because Laghu, Ushna and Teekshna Guna. It also does Srotoshodhana, rasa and Rakta shodhana. $^{16}$ it has antibacterial and antihelmentic activity. ${ }^{17}$

\section{For Raktashodhana:}

Mahamanjishtadhi Kashaya - It contents Manjishtha (Rubia cordifolia), Musta (Cyperus rotandus), Kutaja (Holarrhena antidysentrica), Guduchi (Tinospora cordifolia), Kushtha (Saussurea lappa), Nagara (Zingiber officinalis), Bharangi (Clerodendron serratum), Kshudra (Solanum xanthocarpum), Vacha (Acorus calamus), Nimba (Azadirachta indica), Haridra (Curcuma longa), Daruharidra (Berberis aristata), Haritaki (Terminalia chebula), Bhibhita Terminalia bellirica), Amalaki (Emblica officinalis), Patola (Trichosanthus dioica), Katuki (Picrorrhiza kurroa), Murva (Marsdenia tenacissimia), Vidanga (Embelia ribes), Asana 
(Prerocarpus marsupium), Chitraka

(Plumbago zeylanica), Shatavari

(Asparagus racemosus), Trayamana

(Gentiana kurroo), Pippali (Piper longum),

Vasa( Adhatoda vasica), Bhringaraja

(Eclipta alba), Mahadaru (Cedrus deodara),

Patha (Cyclea peltata), Khadira (Acasia catechu), Chandana (Santalum album),

Trivrita (Operculina turpenthum), Varuna (Crataeva nurvala), Kiratatikta (Swertia chirata), Bakuchi (Psoralea corylifolia), Kritamala (Cassia fistula), Shankhotaka (Streblus asper), Mahanimba (Melia azadirach), Karanja (Pongamia pinnata), Ativisha (Aconitum heterophyllum), Jala (Pavonia odorata), Indravaruni (Citrullus chollocynthis), Ananta (Hemidesmus indicus), Parpata (Fumaria indica). These drugs are Kapha Pittahara, Raktashodhaka, Vranaropaka, Shothaghna, Krumighna. It helps to maintain healthy blood circulation. It is also works as an immune-modulator. The Mahamanjisthadi Kwath ingredients give strength to the working of the immune system. This used to ensure improved functioning of the liver and kidney. This helps ensure blood purification happens in a natural way. Manjistha is one of the ingredients in this medicine that has a helpful effect on the liver and the lymphatic system. This helps to purify blood in a natural way by helping expel toxins from the body. which might help in purification of blood by removing toxins. It also has anti-inflammatory, anti- microbial properties which helpful in reducing the inflammation and enhances the healing of lesion by Vrana ropana karma. ${ }^{18}$

\section{Sthanika chikitsa}

Karanja taila- It contents Karanja (Pongamia pinnata), Saptachada (Alstonia scholaris), Langli (Gloriosa superba), Snuhi (Euphorbia nerifolia), Arka (Calotropis procera), Chitraka (Plumbago zeylanica), Nisha (Curcuma longa), Visha (Aconitum ferox), Tila taila (Oil Sesamum indicum), Gomutra (Cow urine). These are Kandughna which acts as antipruritic and also has Ropana, Vishagna and Kustahara. Karanja taila has the properties of Teekshna guna, Tikta, Kashaya rasa and Ushna veerya. By its Teekshna guna and Ushna veerya it balances Vata and Kapha doshas, ${ }^{19}$ It helps in healing of lesions, and due to Vishagna property it acts as antiinflammatory by reducing the inflammations. It also acts as Raktaprasadaka which is good for nourishing Rakta dhatu. The essential oil obtained from P.pinnata leaves showed marked effect in vitro antibacterial activity against B.anthracis and Sal. typhi. The oil was also active against B. mycoides, B.pumilus, Esch. coli, Sar. lutea, Staph. aureus, Staph. albus and Xanth. campestris. Shigella sp. proved to be resistant to the 
oil.The essential oil from P. pinnata showed mild antifungal activity against keratinophillic fungi viz., Verticillium tenuipes, Malbranchea pulchella, Keratinophyton-tereum, and Chrysosporium tropicum. ${ }^{20}$ Acts as antimicrobial, anthelmintic, germicidal, antipruritis, anti-inflammatory and antidiabetic. Thus, the soft and gentle massage improves blood circulation. The snigdhata present in the taila pacifies dryness. The ingredients or the chemical composition present in the taila act as antimicrobicidal, antibacterial, skin dermatosis. Application of Karanja taila provide relief in symptoms like Kandu, Rookshata, Twak sputana. ${ }^{21}$

\section{Shamana aushadhis}

Gandhaka rasayana: it contents Sita (Saccharum officinarum), Shuddha Gandhaka (purified Sulphur), Ghritam (Ghee), Ela (Elletaria cardamomum), Twak (Cinnamomum verum), Patra (Cinnamomum tamala), Nagakesara (Mesua ferrea), Guduchi (Tinospora cordifolia), Pathya (Terminalia chebula), Aksha (Terminalia bellirica),Dhatri (Phyllanthus emblica),Shunti (Zingiber officinale), Bhringaraja (Eclipta prostrata), Adraka (Zingiber officinale). ${ }^{22}$

It is good for skin ailments because it is Twachya, Krimighna, Vishghna and Raktashodhaka. It has antimicrobial, antifungal and anti-viral effect which helps in removing harmful microbes from the body. It also having Rasayana property, due to this property it helps to reduce the inflammation by enhancing strength and immunity of the patient. Sulpher has been associated constituent in sulphonemides, which act as antimicrobial agent. This groups of drugs have been proved its act by inhibiting folic acid metabolism in susceptible bacteria and preventing their growth. Gandhaka rasayana in higher concentration shows similar antifungal activity in comparison with fluconazole. Sulphonemides and fluconazole act only as antimicrobial agent and may produce side effect on the human beings but Gandhaka rasayana not only act as antimicrobial agent but it have other additional properties like rejuvenation and helps to promote positive health by increasing Immunity and making the body resistant against disease causing factors $^{23}$

\section{2) Chandraprabha vati:}

It contents Gugglu (Commiphora mukul), Shilajit (Asphaltum), Sharkara (Sugar), Karpura (Cinnamomum camphora), Ativisha (Aconitum heterophylium), Haridra (Curcuma longa), Vacha (Corus calamu), Musta (Cyperus rotandus), Amalaki (Emblica officinalis), Haritaki (Terminalia bellirica), Bibhitaki (Terminalia chebula), Chavya(Piper laba), 
Bhunimba (Andrographis paniculate),

Vidanga (Embelia ribes), Devdaru (Cedrus deodara), Dhanyaka(Coriander sativum), Guduchi (Tinospora cordifolia), Chitraka twaka (Plumbago zeylanica), Shunthi (Zingiber officinalis), Darvi (Berberis aristate), Maricha (Piper nigrum), Pippali moola (Piper longum root), Gaja pippali (Piper chaba fruit), Sarjikshara (Sodium carbonate), Yavakshara (Potassium carbonate), Saindhava lavana (Rock salt), Suvarchala lavan (Sodium carbonate), Vida lavana (Black salt), Swarnamakshika bhashma, Copper pyritis), Trivrita (Operculina terpenthum), Danti moola (Baliospermum montanum), Twaka (Cinnamomum zeylanicam), Tamala patra (Cinnamomum tamala), Ela (Elettaria cardamomum), Vanshalochana (Bambusa arundinacea), Lauha bhashma (Ferric ash).which is Sheeta guna in nature, and also having the properties like Tridosa shamana and Kushtahara (helpful in skin ailments). It also does Balya and Rasayana kaarma which enhances the strength and healing factors of patient. ${ }^{24}$

3) We selected Arogyavardini vati,- It contents Haritaki (Termanalia chebula), Bibhitaki (Termanalia bellirica), Amalaki (Emblica officinalis), Shilajatu (Asphaltum), Gugglu (Commiphora mukul), Chitrakamoola (Plumbago zeylanica), Kutaki (Picrorhiza kurroa),
Nimbapatra swarasa (Azadirecta indica), Shudhdha parada(Herbal purified mercury), Loha bhashma (Ash obtained from iron), Shuddha Gandhaka (Purified sulphur), Abhraka bhashma (purified mica), Tamra bhashma (Ash obtained from copper). ${ }^{25}$ It is having anti-pruritic effect which is helpful in reducing itching. And also enhances digestive effect because of Deepana and Pachana properties. Arogyavardhini vati improves overall good health by balancing all the three Dosha. This is known as natural liver detoxifying and fatty liver remedy. It promotes balance and maintains the liver function as well as a healthy digestive system. Arogyavardhini vati is helpful in the Shoshan of different excess Snigdha dravyas present in the body. It also does the Pachan of Drava and Kleda and does the Raktavardhana. ${ }^{26}$ Also helpful in detoxification body by Malashhudhi.

4) Khadhirarishta- Khadira (Acacia catechu), Devadaru (Cedrus deodara),

Bakuchi (Psoralea corylifolia), Darvi (Berberis aristata), Haritaki (Terminalia chebula), Vibhitaki (Terminalia bellirica), Amalaki (Emblica officinalis), Dhataki (Woodfordia fruticosa), Kakkola/Takkola (Piper cubeba), Nagakeshara (Mesua ferrea), Jatiphala (Myristica fragrans), Lavanga (Syzygium aromaticum), Ela (Elettaria cardamomum), Twak 
(Cinnamomum

Patra (Cinnamomum

zeylanicum), tamala),

Krishna/Pippali (Piper longum), Makshika

(Honey), Sharkara (Sugar candy)

It is Twakprasadhaka, Raktapradhaka, Krumighna and Kandughna whic is effective for most of the skin ailments. ${ }^{27}$ Khadirarishta shows significant effect on antibacterial spectrum against $E$. coli, $S$. aureus, and $S$. enterica bacterial strains. The mechanism of action of Khadirarishta seems to be linked with the disruption of bacterial membrane permeability which leads to the smooth entry of active compounds, efflux of nucleotide material and $\mathrm{K}^{+}$ions. The four major marker compounds viz., gallic acid, catechin, ellagic acid, and eugenol. Study shows that Khadirarishta has antibacterial potency and has a vigorous effect on the bacterial cell wall and membrane permeability. This could be due to the presence of identified marker compounds in this herb-decoction based Ayurvedic traditional formulation. ${ }^{28}$ It has the anti-inflammatory, anti-pruritic and anti-microbial action which helps in clearing inflammation, itching and microbes.

5) Patoladi Kashaya tab- It contents Patola (Trichosanthes dioica), Amla (Emblica officinalis), Haritaki (Terminalia chebula), Vibhitaki (Terminalia bellirica), Guduchi (Tinospora cordifolia), Musta(Cyperus rotandus), Chandana (Santalum album), Murva, Rohini, Patha . Key ingredients also having Kushtaghana, Kandughana, twakadosha nashana. ${ }^{29}$

\section{CONCLUSION}

The patient suffering from psoriasis was successfully treated with Ayurvedic shamana therapy. Nidanaparivarjana was also a necessary part of treatment. Treatment was given according to Lakshana and doshas. Drugs used in medicationhelps for samprapti vighatana. From abovr discussion it can conclude that these medicine are beneficial for patient. Thi case study is evidence for successful management of Kitibha kushtha by Shamana and Sthanika chikitsa.

\section{REFERENCE}

[1] Yashpal Munjal, API textbook of medicine, $10^{\text {th }}$ edition, published by Yash pal Munjal and on behalf of the associations of physicians of India, 2015, page no 678

[2] Sunil Dongra, Savita Yadav, Indian journal of dermatology, Venereology and Leprology. November- December 2010. Volume 76. Issue 6

[3] Tripathi R. Charaka Samhita Chikitsasthan 7/13 Chaukhamba Sanskrit Pratishthan Delhi: 2009, Pp 182 
[4] Tripathi R. Charaka Samhita Chikitsasthan 7/22 Chaukhamba Sanskrit Pratishthan Delhi: 2009 Pp 285

[5] Dr.kaival Krushna Thakaral, Susruta Samhita nidanasthana Chaukhamba Orientalia, Varanasi: 2014 Pp752

[6] Tripathi B. Ashtanga Hrudayam Nidan Sthan 14/32 Chaukhamba Sanskrit Pratisthan Delhi: 2017 Pp 530

[7] Sneha Patil,Prashanth Bhat. Importance of repeated shodhana in Kitibha kushtha(Psoriasis) a case study. International journal of Ayurveda and pharma research.March 2021, Vol 9, issue 3, ISSN-2322-0902

[8] Shri Rajeshwardatta Shastri Editor(S), (Reprint 2008 Ed.). Bhaishajya Ratnawali Of Kaviraj Shri Ambikadtta Shastri, Prathama; Jwara Chikitsa Prakarana: Chapter 5, Verse 483. Varanasi: Chaukhamba Prakashana, 2008; P. 120

[9] Vd. Yogita A. Surpam and Vd. R. M. Khiyani. Critical Review And Probable Mode Of Action of Agnitundi Rasa - A Herbomineral Formulation. world jounal of pharmaceutical research. Volume 10 , issue $9,625-637$

[10] Sharma PV, editor. Madanphalkalpa adhyaya. Verses 5. In Charak Samhita of Agnivesha, Kalpastana. 8th ed. Varanasi, India: Chukhambha Orientalia;2001. p. 806

[11] Hiware S, Parwe S. Role of Nitya Virechana in Medoroga-A case study. IAMJ 2;2018: 1085-9.

[12] Anonymous.The Ayurvedic Formulary of India: Part I, 2nd revised English edition, Vol. 7. Delhi: Ministry of Health and Family Welfare, Govt. of India. Avipattikar Churna;2003. p. 41

[13] Shatri K. Charaka Smhita with Vidhyotini Hindi commentary Chikitsa Sthan, Vol. 7. Varanasi: Chakhambha Bharti Academy;2008. p. 128-268.

[14] Mishra S.editor krumirogadhikara, chapter 11 verse29-32 in bhaisajya ratnavali by Govind das Varanasi india by chaukhamba surbhari prakashana 2007,page no.369

[15] Snehal bhende. Shweta Pware, Role of nitya virechana and shamana chikitsa in tne management of Ekakushtha with special respect to plaque psoriasis; a case study. Journal of Indian 
system of medicine. 2020 volume 8 issue 1

[16] Dr. Brahmananda Tripathi, Sharangadhar samhita, edition 2015, chaukhamba Surbharati prakashan, Varanasi, pg no169

[17] SV PK, Sandeep M, Kamal D, Nishanth BC, Megharaj HK, Gurucharan DN. Antibacterial and Anthelmintic activity of selected fermented Ayurvedic herbal formulations

[18] Kaviraj Govinddas Sen, Bhaisajya Ratnavali, Kushtharoga chikitsa, Chaukhamba surbhari prakashana 2019 page no 866

[19] Kaviraj Govinddas sen, Bhaisajya ratnavali, Visarpa rogadhikara, Chaukhamba surbhari prakashana 2019 page no 111

[20] Vijendra K, Shilpy G. Pharmacological Evaluation And Action Of Karanja Patra Kalka Siddha Taila In Striae Gravidarum.

[21] Jadhav V, Ramesh BN, MR YB, MR SR. Available online through.

[22] Jossi SS. Yoga Ratnakara Rasayanadhikara. Chaukhambha Samskrita Series Office. In: Shastri Bhramshankar., editor. 7th ed. Varanasi: Chaukhambha samskrita series office; 2001. p. 834.

[23] Saokar RM, Sarashetti RS, Kanthi V, Savkar M, Nagthan CV. Screening of antibacterial and antifungal activity of gandhaka rasayana-an ayurvedic formulation. International Journal of Recent Trends in Science And Technology. 2013;8(2):134-7.

[24] Murthy KRS.Sharangadhara Samhita madhyama khanda by Chaukhamba Orientalia, Varanasi, India 2017, page no.105

[25] Kaviraj Govinda Das Sen. Bhaisajyaratnavali. Siddhipada Hindi Commentary, Prof. Siddhinandana Mishra editor. 1st edition. Kustharogadhikara, Chapter no-54, Verse no-117, Varanasi: Chaukhamba Surbharati Prakashana; 2012.p.871

[26] Pal S, Ramamurthy A, Mahajon B. Arogyavardhini Vati: A theoritical analysis. Journal of Scientific and Innovative Research. 2016;5(6):225-7

[27] Khadira arishtha?

[28] Balkrishna A, Gupta AK, Gupta A, Singh P, Singh K, Tomar $\mathrm{M}$, Rajagopal D. Antibacterial Activity and Mechanism of Action of an Ayurvedic formulation 
Khadirarishta. Journal of Herbal

Medicine. 2021 Aug 26:100509

[29] Dr.G. Prabhakara Rao

Sahastrayoga kasaya yoga

prakarana kushthahara kasaya

Chaukhamba publications new

delhi 2019, page no 111 